\title{
PROSES PEMBUATAN ITEM TES OLIVE, ONLINE LISTENING FOR INDIVIDUAL PRACTICE
}

\author{
Yohana Ika Harnita Sari, M.Hum. \\ Prodi Bahasa Inggris Sekolah Vokasi Universitas Gadjah Mada \\ Emal:yohanaikahs@ugm.ac.id
}

\begin{abstract}
:
This article aims at describing the test item making process in developing OLIVE, Online Listening for Individual Practice. OLIVE is a combination of CALL (Computer Assisted Language Learning) and ICT (Information Communication Technology), which is an elearning format. It is a web application prepared by Sekolah Vokasi Universitas Gadjah Mada Yogyakarta to enhance listening skill for non-English major students. OLIVE provides supplementary listening materials in the form of test which can be self-accessed online outside the classroom. There are four parts of the listening practice served in OLIVE; Short Conversation, Question-Response, Longer Conversation, and Talks. Meanwhile, the process of the test making includes design, operationalization, and administration.
\end{abstract}

Keywords: test item, listening test, OLIVE

Intisari:

Artikel ini bertujuan untuk mendeskripsikan proses pembuatan item tes dalam mengembangkan OLIVE, Online Listening for Individual Practice. OLIVE merupakan suatu aplikasi web e-learning yang menggabungkan pembelajaran berbasis computer, yang biasa disebut CALL (Computer Assisted Language Learning), dan TIK (Teknologi Informasi dan Komunikasi). Aplikasi web ini disiapkan oleh Sekolah Vokasi Universitas Gadjah Mada Yogyakarta untuk meningkatkan keterampilan menyimak mahasiswa dari program studi non-bahasa Inggris. OLIVE menyediakan materi tambahan untuk menyimak yang berupa tes yang bisa diakses mandiri secara online di luar kelas. Ada empat bagian dari tes menyimak yang disajikan di OLIVE, yaitu Percakapan Singkat, Tanya-Jawab, Percakapan Panjang, dan Monolog. Sementara itu, proses pembuatan item tes OLIVE meliputi desain, operasionalisasi, dan administrasi.

Kata kunci: item tes, tes menyimak, OLIVE 


\section{Pendahuluan}

OLIVE, Online Listening for Individual Practice, merupakan aplikasi web yang dirancang oleh Sekolah Vokasi Universitas Gadjah Mada Yogyakarta untuk meningkatkan keterampilan menyimak mahasiswa dari program studi non-bahasa Inggris karena seluruh mahamahasiswa Sekolah Vokasi UGM harus mengikuti tes kemampuan Bahasa Inggris untuk mahasiswa kejuruan / vokasi (TEVocS Test) sebelum mereka lulus dari UGM. Persyaratan tersebut menyebabkan perlunya persiapan untuk tes tersebut yang diakomodasi dalam mata kuliah wajib untuk setiap program studi, yaitu Bahasa Inggris I dan II. Mata kuliah tersebut menggabungkan aktivitas kelas yang dipimpin guru (teacher-led learning) dengan pembelajaran mandiri (independent learning), yang disebut pembelajaran campuran (blended learning). OLIVE menyediakan materi menyimak tambahan berupa tes yang bisa diakses sendiri secara online di luar kelas.

Sebagai pembelajaran campuran, aktivitas belajar dilakukan baik offline, di kelas, dan online, di luar kelas, untuk meningkatkan pembelajaran mandiri atau pembelajaran secara individu yang dilakukan oleh mahamahasiswa. Dengan demikian pembelajaran mandiri dapat terealisasikan. Tes diunggah di web OLIVE sehingga bisa diakses oleh mahasiswa secara online. OLIVE memiliki dua target, yaitu meningkatkan kemampuan mendengar mahasiswa (target umum) dan untuk mencapai nilai bagus dalam TEVocS (target khusus).

Dalam penerapannya, mahasiswa akan menerima pembelajaran mengenai materi utama dan juga tugas yang dipimpin guru di dalam kelas. Kemudian, mereka akan melakukan pembelajaran melalui media elektronik (e-learning) secara mandiri. Setelah itu, para mahasiswa harus mengevaluasi aktivitas mereka, di dalam atau di luar kelas, dengan guru. Harapannya, para mahasiswa akan sampai pada sebuah pernyataan bahwa mereka terbantu oleh adanya OLIVE untuk mengembangkan kemampuan menyimak mereka.

Sebagai bentuk e-learning, OLIVE menggabungkan Pembelajaran Bahasa berbasis Komputer / CALL (Computer Assisted Language Learning) dan teknologi informasi komunikasi (TIK) / ICT (Information Communication Technology). Mereka membuat pembelajaran bahasa menjadi lebih 
dinamis sehingga tidak hanya dilakukan di kelas dan mengerjakan karya berbasis kertas. Young (2003) mendukung pernyataan tersebut dengan mengatakan bahwa "Sungguh-sungguh, teknologi informasi komunikasi (TIK) telah mengubah lingkungan pembelajaran bahasa dan pemerolehan kemampuan baca-tulis menjadi pembelajaran bahasa yang dinamis."

Hussain (2004) menyatakan bahwa di Malaysia, banyak dosen menggunakan materi elektronik untuk mendukung kuliah mereka guna memberi penekanan pada materi tertentu. Dia menambahkan bahwa "... pendidik perlu mengembangkan dan memberikan pengajaran yang relevan, up-to-date, komprehensif, dan sesuai dengan kebutuhan mahasiswa di dunia kerja. Media elektronik, seperti CD-interaktif dan multimedia, memungkinkan mahasiswa untuk mengalami beberapa teknologi yang digabungkan di lingkungan belajar dan mengajar." Beliau melakukan penelitian terhadap 52 mahasiswa di Malaysia untuk mengetahui apakah pengalaman menerapkan elearning menjadi faktor utama penyebab meningkatnya kemampuan berbahasa Inggris mahasiswa. Hasilnya adalah mahasiswa yang mengalami blended learning dengan perangkat lunak multimedia menunjukkan kemampuan berbahasa Inggris yang lebih baik daripada mahasiswa yang tidak mengalami pembelajaran tersebut. Kavaliauskiene \& Anusiene (2009) juga melakukan penelitian tentang penggunaan podcast untuk meningkatkan kemampuan menyimak mahasiswa di Universitas Mykolas Romeris, Lituania. Podcast merupakan program radio yang terekam dan dapat diunggah melalui internet. Penelitian tersebut menyatakan bahwa podcast yang merupakan media menyimak secara online dan mandiri memungkinkan mahasiswa berlatih menyimak di luar kelas sehingga dapat meningkatkan keterampilan menyimak mereka.

Christian (2005) meneliti beberapa mahasiswa dari Republik Rakyat China (RRC) yang belajar di National Institute of Education (NIE) Singapura pada pusat pembelajaran mandiri, yangmana mereka harus mengembangkan otonomi / kebebasan dalam pembelajaran bahasa Inggris mereka. Pusat pembelajaran mandiri tersebut menyediakan materi pembelajaran dari CD, DVD, dan internet 
untuk meningkatkan kemampuan bahasa Inggris mereka. Melalui pusat pembelajaran mandiri tersebut mahasiswa juga dimungkinkan untuk mengakses materi dari manapun bahkan dari luar kampus. Mereka menikmati pembelajaran mandiri dan mereka mendapatkan manfaat dari pembelajaran tersebut.

Selain tiga peneliti diatas, Kumar (2008) melakukan penelitian untuk menggambarkan kelebihan dan kekurangan Pembelajaran Bahasa berbasis Komputer (CALL) di kelas Bahasa Inggris sebagai bahasa kedua / ESL (English as a Second Language). Ada banyak keuntungan dari CALL yang dapat diperoleh. Beberapa diantaranya adalah CALL mendukung otonomi / kebebasan dalam belajar, menyediakan materi pembelajaran yang bervariasi, melayani pembelajaran jarak jauh, memberi kesenangan dalam pembelajaran, memungkinkan mahasiswa untuk melakukan evaluasi diri, dan mampu memberikan nilai secara cepat dan akurat. Sebaliknya, CALL memiliki beberapa keterbatasan yang berkaitan dengan masalah teknis yang mungkin muncul dan kurangnya keterampilan terkait pengoperasian komputer dan perangkat lunak atau aplikasi tertentu.

Terkait dengan penelitianpenelitian diatas, TIK yang sangat umum dipakai pada proses pembelajaran bahasa saat ini adalah internet melalui media komputer. Banyak hal yang bisa dilakukan dan didapatkan melalui internet, termasuk melakukan pembelajaran jarak jauh atau menyediakan tes berbasis komputer. Tes berbasis komputer adalah tes terstandar yang paling banyak dijumpai saat ini (Brown, 2001). Dengan alasan tersebut, makalah ini bertujuan untuk membahas tentang tes bahasa Inggris menggunakan OLIVE. Fokusnya adalah pada penggambaran proses pembuatan butir tes dalam OLIVE.

\section{Pengujian Bahasa}

Pada dasarnya, ada lima jenis tes bahasa yang berbeda, yaitu tes bakat (aptitude test), tes kemampuan (proficiency test), tes penempatan (placement test), tes diagnostik (diagnostic test), dan tes prestasi (achievement test) (Brown, 2004). (1) Tes bakat bahasa adalah tes yang dilakukan untuk mengetahui kemampuan seseorang atau kemampuan umum untuk belajar bahasa asing dan untuk 
memprediksi keberhasilan akhir dengan mempelajari bahasa tersebut, misalnya Modern Language Aptitude Test (MLAT). Terdapat lima sub-tes yang berbeda di MLAT; yaitu adalah test tentang angka (number learning), naskah fonetik (phonetic script), ejaan (spelling clues), jenis kata dalam kalimat (words in sentences), dan kata berpasangan (paired associates). (2) Tes kemampuan adalah tes untuk mengukur kompetensi umum dalam bahasa, bukan kemampuan bahasa tertentu atau berdasarkan mata kuliah tertentu atau kurikulum tertentu. TOEFL, TOEIC, dan IELTS adalah contoh uji profisiensi / tes kemampuan. (3) Tes penempatan bertujuan untuk menempatkan seseorang sesuai dengan tingkat kurikulum, mata pelajaran, atau sekolah tertentu. (4) Tujuan tes diagnostik adalah untuk mendiagnosis aspek bahasa tertentu. Tes ini memberikan informasi detail tentang subkategori yang perlu dipelajari mahasiswa. Sebagai contoh, tes dalam pelafalan dapat memberikan beberapa informasi tentang penekanan dan irama, intonasi, bunyi vokal, bunyi konsonan, dan faktor lainnya. (5) Tes prestasi adalah untuk menguji materi tertentu dalam kurikulum yang telah dipelajari dalam kurun waktu tertentu atau setelah menempuh mata kuliah tertentu.

$$
\text { Selain itu, Henning }
$$
mengusulkan beberapa jenis uji bahasa berdasarkan pada tujuan pengujian yang bisa dikembangkan oleh para pembuat tes. Jenis uji bahasa tersebut dibedakan dalam beberapa kategori besar. Pertama, tes objektif dan subyektif (objective and subjective tests). Kedua tes tersebut dibedakan dari cara penilaiannya. Kedua, tes langsung dan tidak langsung (direct and indirect tests) yang didasarkan pada tingkat penggunaan bahasa dalam situasi komunikasi nyata. Ketiga, tes poin khusus / kekhasan dan integratif (discrete points and integrated tests) adalah untuk menilai kinerja di ranah yang sangat terbatas dari suatu bahasa. Di sisi lain, tes tersebut berfungsi untuk mengukur variasi yang lebih besar dari kemampuan berbahasa. Yang keempat adalah tes bakat, prestasi, dan kemahiran (aptitude, achievement, and proficiency tests). Tes bakat adalah untuk menilai kecocokan kandidat untuk program tertentu. Tes ini sering disebut tes kecerdasan atau uji skrining. Tes prestasi adalah untuk memeriksa seberapa jauh kemampuan mahasiswa terkait dengan tujuan pembelajaran. Selanjutnya, tes 
kemahiran lebih banyak tentang mengukur kemampuan bahasa secara global. Berikutnya adalah tes berdasarkan kriteria tertentu dan tes terstandar (criterion- or domainreferences and norm-referenced or standardized tests). Uji kriteria direncanakan sebelum instruksi dirancang dan peserta tes dievaluasi berdasarkan penguasaan domain konten pembelajaran. Sementara itu, tes terstandar harus diujikan pada sampel besar sebelum digunakan, sehingga standar tertentu dapat diperoleh. Yang terakhir adalah tes kecepatan dan tes kekuatan (speed tests and power tests). Dalam tes kecepatan, setiap peserta tes memiliki kemungkinan untuk memberikan jawaban dengan benar pada setiap item, namun tidak disediakan waktu yang cukup sehingga mereka berlomba melawan waktu. Sebaliknya, dalam uji kekuatan, waktu yang cukup disediakan bagi peserta tes, namun mereka harus menghadapi kasus yang sulit untuk dipecahkan.

Alasan pengujian seharusnya beragam dari satu konteks ke konteks lainnya. Dengan demikian, penyusun tes harus menetapkan kriteria pengujian berdasarkan tujuan pengujian. Kriteria umum tersebut dapat digunakan sebagai titik awal dalam pengembangan tes. Kriteria umum tersebut adalah tujuan tes, karakteristik peserta tes, domain kepentingan, konstruksi kepentingan, reliabilitas, validitas, bentuk paralel atau yang disamakan, administrasi dan kepraktisan tes, dan dampak dari tes tersebut (Fulcher, 2010). Kemudian, kriteria-kriteria umu tersebut dapat berfungsi sebagai dasar dalam menentukan jenis tes. Tes berbasis komputer menjadi salah satu di dunia digital saat ini. Kopriva (2008) menyatakan bahwa tes berbasis komputer memiliki beberapa manfaat, seperti kemudahan pengiriman, memperluas jangkauan tes dan memberikan kemudahan bagi para peserta, dan juga lebih fleksibel. Bahkan tes akademik pada umumnya yang menggunankan kertas dan pensil, kini telah beranjak ke tes online (berbasis internet). Selain itu, tes berbasis komputer atau berbasis internet juga mendukung pembelajaran mandiri seperti yang dinyatakan oleh Brown (2004), "Dengan menggunakan inovasi teknologi secara kreatif, penguji akan dapat meningkatkan keaslian, meningkatkan pertukaran secara 
interaktif, dan mendukung otonomi / kebebasan dalam pembelajaran."

Selain itu, ada banyak teknik yang sesuai dengan tujuan, jenis uji, dan keterampilan berbahasa. Beberapa teknik yang mungkin digunakan dalam tes menyimak tersedia dalam banyak pilihan. Teknik-teknik tersebut adalah pilihan ganda, jawaban singkat, pengisian spasi kosong, pemindahan informasi, pembuatan catatan, dikte secara parsial, transkripsi, pengurangan item pilihan, dan penyajian teks (Hughes, 2003).

\section{Tes Menyimak}

Dalam menilai kemampuan mahasiswa pada suatu keterampilan atau keterampilan gabungan, dosen perlu mengamati kinerja mahasiswa. Dengan demikian, dosen harus memutuskan kinerja yang dapat diamati yang mampu mengukur kompetensi mahasiswa. Menyimak merupakan kegiatan yang tak terlihat dan tak terdengar. Akibatnya, semua penilaian keterampilan menyimak harus dalam bentuk tes lisan (dengan respon verbal) atau tes tertulis (dengan tanggapan non-verbal) (Brown, 2004). Kegitan menyimak dapat dikelompokkan menjadi empat jenis berdasarkan penilaian dan prosedurnya. (1) Intensif. Mahasiswa akan menyimak dengan memperhatikan fonem, kata-kata, intonasi, penanda wacana, dan komponen bahasa lainnya. (2) Responsif. Mahasiswa akan menyimak ucapan, pertanyaan, perintah, pemeriksaan pemahaman, dan rangkaian bahasa singkat lainnya dan memberi tanggapan. (3) Selektif. Mahasiswa akan menyimak untuk memahami monolog singkat untuk mendapatkan informasi detail. (4) Ekstensif. Mahasiswa akan menyimak percakapan untuk mendapatkan intisari dan gagasan utamanya dan juga untuk membuat kesimpulan (Brown, 2004).

Kegiatan menyimak di atas diperinci dalam keterampilan menyimak secara mikro (micoskills) dan makro (macroskills) (tercantum dalam Tabel 1) sehingga tujuan penilaian yang spesifik mudah untuk diidentifikasi. 


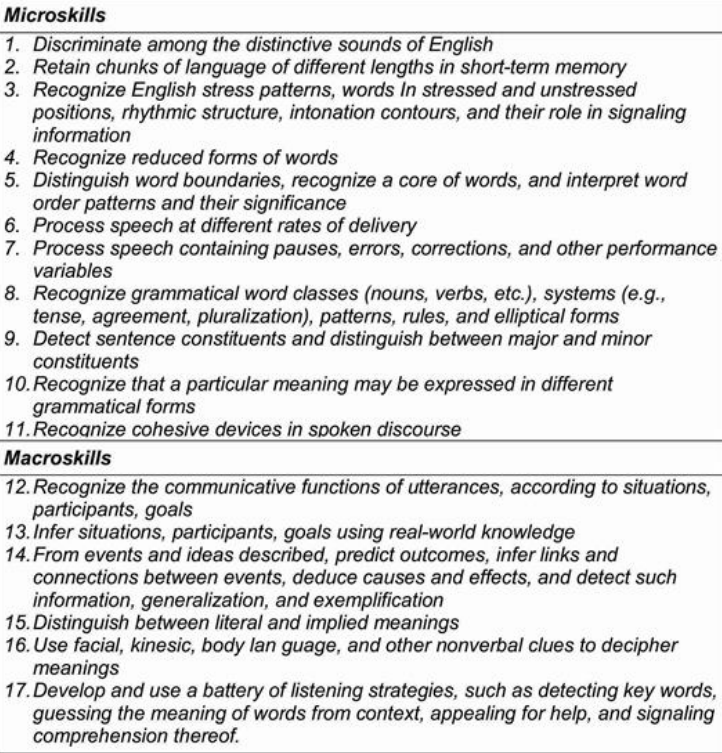

7.Develop and use a battery of listening strategies, such as detecting key words, guessing the meaning of words from context, appealing for help, and signaling comprehension thereof.

Tabel 1. Keterampilan Menyimak secara Mikro (micoskills) dan Makro (macroskills) (diambil dari Brown, 2004)

\section{Tes Kemahiran Bahasa Terstandar}

TEVocS yang merupakan singkatan dari Test of English for Vocational Students adalah tes yang dirancang oleh English Program Sekolah Vokasi Universitas Gadjah Mada (Copyright @) 2015 Sekolah Vokasi Universitas Gadjah Mada) untuk mengukur kemampuan bahasa Inggris mahasiswa vokasi. Tes ini menguji dua keterampilan bahasa, yaitu menyimak dan berbicara. Tes ini juga mempersiapkan mahasiswa untuk orientasi profesional mereka (Sekolah Vokasi Universitas Gadjah Mada, 2015). Tes TEVocS terbagi menjadi dua bagian, yaitu Bagian Menyimak dan Bagian Berbicara. Bagian menyimak terdiri dari empat sub-bagian, masing-masing terdiri dari sepuluh pertanyaan dengan beberapa item pilihan, sedangkan bagian pembicaraan terdiri dari tiga sub-bagian: Memperkenalkan Diri, Bersosialisasi, dan Di Tempat Kerja. Pesrta tes akan membutuhkan sekitar 45 menit untuk melakukan keseluruha bagian tes. Format TEVocS disajikan pada Tabel 2.

\begin{tabular}{|l|l|l|l|}
\hline $\begin{array}{l}\text { Bagian } \\
\text { Menyimak } \\
\text { (Listening } \\
\text { Section) }\end{array}$ & 30 menit & $\begin{array}{l}\text { Bagian } \\
\text { Berbicara } \\
\text { (Speaking } \\
\text { Section) }\end{array}$ & 15 menit \\
\hline Sub-bagian I & $\begin{array}{l}\text { Percakapan } \\
\text { Singkat (Short } \\
\text { Conversation) }\end{array}$ & Sub-bagian I & $\begin{array}{l}\text { Memperkenalkan Diri } \\
\text { (introducing Self) }\end{array}$ \\
\hline Sub-bagian II & $\begin{array}{l}\text { Tanya-Jawab } \\
\text { (Question- } \\
\text { Response) }\end{array}$ & Sub-bagian II & $\begin{array}{l}\text { Bersosialisasi } \\
\text { (Socializing) }\end{array}$ \\
\hline Sub-bagian III & $\begin{array}{l}\text { Percakapan } \\
\text { Panjang (Longer } \\
\text { Conversation) }\end{array}$ & Sub-bagian III & $\begin{array}{l}\text { Di Tempat Kerja (In a } \\
\text { Workplace) }\end{array}$ \\
\hline Sub-bagian IV & Monolog (Talks) & \multicolumn{3}{|l}{} \\
\hline
\end{tabular}

Tabel2. Format TEVocS (diambil dari Sekolah Vokasi Universitas Gadjah Mada, 2015)

Mahasiswa Sekolah Vokasi Universitas Gadjah Mada wajib mendaftarkan diri dan mengikuti tes TEVocS di Pusat Pengembangan Vokasional (VDC Vocational Development Center) SV UGM.

\section{OLIVE, Online Listening For Individual}

\section{Practice}

OLIVE adalah singkatan dari Online Listening for Individual Practice. Seperti yang telah dinyatakan di atas, OLIVE merupakan realisasi dari blended learning bagi mahasiswa Sekolah Vokasi UGM. Karena mahasiswa vokasi dipersiapkan untuk dunia kerja, mereka 
akan dihadapkan pada kegiatan menyimak dalam konteks dunia kerja dan kehidupan sehari-hari dalam konteks masyarakat. Pengalaman komunikasi dalam konteks dunia kerja, terutama dalam interaksi lisan, yang mencakup keterampilan menyimak dan juga berbicara sangat penting bagi mahasiswa vokasi. Kantelinen \& Airola (2009) menyatakan bahwa:

Komunikasi di tempat kerja mencakup beberapa keterampilan, yaitu interaksi lisan, membaca, dan menulis, walaupun cakupan dan konteks komunikasi bervariasi dari satu tempat kerja dengan tempat kerja yang lain. Interaksi lisan adalah bagian paling penting dari keberhasilan komunikasi di tempat kerja. Kebutuhan interaksi lisan dalam bahasa asing paling tinggi berada di bidang bisnis. Karyawan membutuhkan bahasa asing dalam situasi lisan seperti obrolan ringan, percakapan di telepon, komunikasi dengan pelanggan, dan menjamu tamu.

Keterampilan komunikasi mereka dibutuhkan untuk menyukseskan komunikasi mereka di tempat kerja nantinya, dan kemampuan berbahasa adalah elemen komunikasi yang dapat menjembatani komunikasi seperti yang dijabarkan oleh Kantelinen \& Airola (2009) bahwa "Jika memiliki kompetensi kemampuan berbahasa, sorang karyawan dapat bekerja sama dan berkomunikasi dengan rekan kerja di berbagai negara, sehingga hal ini menghilangkan hambatan dalam mobilitas dan meningkatkan kerjasama dan jejaring internasional."

Terkait keterampilan komunikasi yang dibutuhkan terutama dalam keterampilan menyimak, ada empat bagian yang disajikan dalam OLIVE; yaitu Percakapan Singkat, Tanya-Jawab, Percakapan Panjang, dan Monolog. Bagian pertama adalah Percakapan Singkat. Fokus dari percakapan singkat ini adalah untuk memahami pesan yang disampaikan oleh lawan bicara. Bagian nomor dua adalah Tanya-Jawab. Dalam Tanya-Jawab ini mahasiswa diharapkan dapat menyatakan tanggapan / jawaban yang benar untuk ucapan atau pertanyaan tertentu. Bagian selanjutnya adalah Percakapan Panjang. Para mahasiswa akan mendengarkan beberapa percakapan panjang dan menjawab beberapa pertanyaan yang berkaitan dengan isi percakapan. Yang terakhir, beberapa monolog ditampilkan dan diikuti oleh pertanyaan terkait detail dari monolog tersebut. Semua bagian dalam tes keterampilan menyimak 
tersebut disajikan dalam bentuk pilihan ganda dan setiap bagian tes terdiri dari sepuluh item tes / pertanyaan.

OLIVE dapat diakses secara online melalui olive-svugm.com. Para mahasiswa harus login menggunakan username dan password mereka. Setelah itu, mereka dapat melakukan tes pada waktu dan alokasi waktu yang telah ditetapkan. Halaman awal OLIVE disajikan pada Gambar 1.

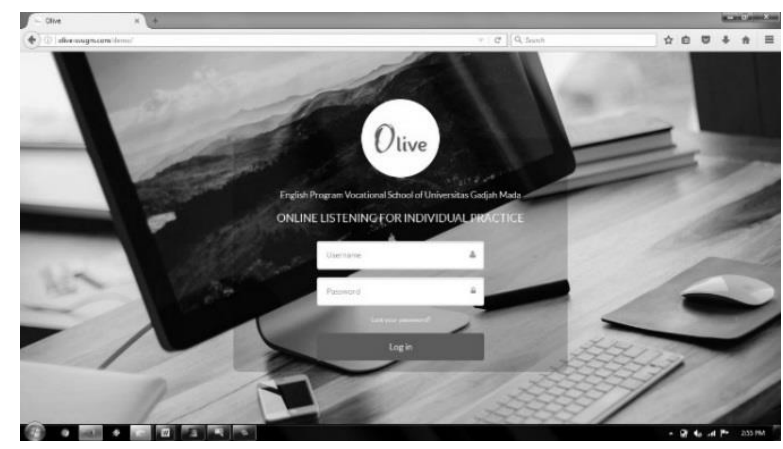

Gambar 1. Homepage OLIVE (Sumber: olive-svugm.com)

Dengan melakukan tes di OLIVE, mahasiswa diharapkan dapat mencapai hasil pembelajaran yang ditargetkan. Mereka mampu mengembangkan keterampilan menyimak mereka secara umum. Kemudian, sebagai targetnya, mereka harus bisa mencapai skor 60 untuk rata-rata tes mendengar dan berbicara di TEVocS sebagai persyaratan kelulusan mereka seperti yang baru dinyatakan dalam Keputusan Dekan Sekolah Vokasi Universitas Gadjah Mada Jurnal Lingua Aplicata Volume 1, Nomor 1 September 2017
Nomor 10 / UN1.SV / SK / 2017 (Sekolah Vokasi Universitas Gadjah Mada, 2017). Selanjutnya OLIVE dapat mempromosikan otonomi / kebebasan belajar karena ini adalah aplikasi berbasis web yang dapat diakses di luar kelas.

\section{Proses Pembuatan Tes Olive}

Proses pembuatan item tes ini diadaptasi dari Test Development yang diusulkan oleh Bachman dan Palmer (1996), yang terdiri dari tiga tahap. Ketiga tahap tersebut digambarkan sebagai berikut.

\section{Desain}

Desain adalah proses dimana penyusun tes menggambarkan detail aspek pengujian sehingga tes mampu mengukur keterampilan yang ditargetkan. Aspek detail berupa pernyataan desain yang merupakan hasil akhir dari tahap ini. Pernyataan desain mencakup deskripsi tujuan pengujian, jenis bidang dan tugas, peserta tes, definisi konstruk tes, rencana evaluasi pengujian, dan juga alokasi waktu dan persediaan sumber daya tes. Dengan mengemukakan pernyataan desain, pembuat tes mampu menyusun tugas dalam tes, kerangka (blueprint), dan tes itu sendiri (Bachman dan Palmer, 1996). 
Menggambarkan Tujuan Tes

Ada beberapa poin dari keterampilan menyimak secara mikro (micoskills) dan makro (macroskills) (Brown, 2004) yang menjadi dasar dalam menetapkan tujuan tes listening di OLIVE. Poin-poin tersebut adalah sebagai berikut.

... 1. Membedakan bunyi khas dalam bahasa Inggris. ... 8 . Mengenali kelas kata (kata benda, kata kerja, dll.), sistem (misalnya struktur kalimat berdasarkan penanda waktu, hubungan subjek dan predikat, pluralisasi), pola, aturan, dan bentuk singkat. ... 10. Mengenali bahwa suatu makna tertentu dapat dinyatakan dalam bentuk gramatikal yang berbeda. 11. Mengenali kata penghubung dalam wacana lisan. 12. Mengenali fungsi komunikatif ujaran, sesuai dengan situasi, lawan bicara, tujuan. 13. Menyimpulkan situasi, lawan bicara, tujuan komunikasi menggunakan pengetahuan yang ada. 14. Dari kejadian dan gagasan yang dijelaskan, mampu memprediksi hasil, menyimpulkan hubungan antar kejadian, menyimpulkan sebab dan akibat, dan mendeteksi hubungan seperti ide utama, gagasan pendukung, informasi baru, informasi yang ada, generalisasi, dan contoh yang diberikan. 15. Membedakan antara makna harfiah dan tersirat. ... 17. Mengembangkan dan menggunakan strategi menyimak, seperti menemukan kata kunci, menebak arti kata dari konteks, seruan bantuan, dan pemahaman terhadap isyarat.
Keterampilan mikro dan makro tersebut diakomodasi dalam empat tujuan yang ditetapkan dalam tes menyimak ini. Pertama, tes ini untuk mengukur kemampuan mahasiswa dalam memahami pesan percakapan singkat. Kedua, tes ini menilai kemampuan menanggapi pernyataan atau pernyataan tertentu. Ketiga, tes ini bertujuan untuk memeriksa pemahaman mahasiswa terhadap percakapan yang lebih panjang dalam konteks kehidupan sehari-hari dan tempat kerja. Dan yang terakhir, tes ini dimaksudkan untuk mengevaluasi pemahaman mahasiswa tentang beberapa monolog dalam konteks kehidupan sehari-hari dan tempat kerja. Tujuan atau sasaran yang ditetapkan ini akan mempengaruhi jenis tes yang akan dijelaskan selanjutnya.

\section{Menggambarkan Jenis Bidang dan Tugas} Tes

Fulcher \& Davidson (2007) berpendapat bahwa tugas adalah "bagian pengujian yang paling jelas dan terlihat", sehingga dianggap mudah untuk menggambarkannya. Karena tes ini adalah tes menyimak bagi mahasiswa vokasi yang dipersiapkan untuk dunia kerja, bidang ujinya adalah tempat kerja dan situasi kehidupan sosial. Selain itu, 
untuk tujuan kepraktisan, jenis tugasnya adalah pilihan ganda. Karena tes pilihan ganda termasuk dalam kategori pertanyaan tertutup, hal ini memudahkan dalam mengelola tes tersebut dan lebih efisien dibandingkan dengan menggunakan pertanyaan terbuka. Hal ini sejalan dengan pernyataan Tuckman (1975) bahwa item pilihan ganda "lebih mudah untuk dinilai dan mudah dianalisis" walaupun sulit untuk ditulis karena pembuat tes harus mempertimbangkan pilihan yang masuk akal dan perlu diuji, dianalisis, dan diperbaiki untuk memberi factor pembeda antara pilihan yang benar dan yang salah. Brown (2004) sependapat bahwa format pilihan ganda praktis dan dapat diandalkan. Selain itu, pilihan ganda menawarkan prosedur penilaian yang menghemat waktu, mudah, dan konsisten.

Selain itu, jenis tugas terkait dengan teknik menyimak bagi tingkat menengah yang diterapkan adalah topdown. Teknik top down lebih berfokus pada mengaktifkan konsep, memperoleh makna, memiliki pemahaman global, dan menafsirkan teks (Brown, 2001). Teknik ini memiliki lima tujuan yang masuk dalam latihan-latihan, yaitu:
... 17) Menganalisis Struktur Wacana untuk Menyarankan Strategi Menyimak yang Efektif, 18) Menyimak untuk Mengidentifikasi Pembicara atau Topiknya, 19) menyimak untuk Mengevaluasi Tema dan Motif, 20) Menemukan Gagasan Utama dan Pendukung, 21) Membuat Kesimpulan, (Brown, 2001).

\section{Menggambarkan Peserta Tes}

Mahasiswa yang akan menggunakan OLIVE adalah mahasiswa dari program studi non-bahasa Inggris Sekolah Vokasi Universitas Gadjah Mada Yogyakarta, khususnya mereka yang berada di semester dua. Mahasiswa di tingkat tersebut menjadi sasaran tes karena ketidakseimbangan antara input pembelajaran dan hasil belajar. Berdasarkan pengamatan di beberapa program studi; yaitu bahasa Mandarin, Komputer dan Sistem Informasi, dan Metrologi dan Instrumentasi, hasil ujian tengah semester untuk mata kuliah bahasa Inggris pada prodi-prodi tersebut pada tahun ajaran 2015-2016, menunjukkan bahwa hanya 2 mahasiswa dari 100 mahasiswa yang memiliki nilai menyimak lebih tinggi daripada nilai berbicara dan hanya 4 mahasiswa yang memiliki nilai menyimak lebih dari 60. Ini berarti hampir semua mahasiswa mengalami masalah dengan menyimak. 


\section{Mendefinisikan Konstruk Tes}

Definisi teoretis dari konstruk tes dapat didasarkan pada luaran pembelajaran yang kemampuan bahasa untuk diukur. Ini adalah definisi abstrak yang mencakup keterampilan target, program bahasa, pengetahuan topikal, dan kemampuan bahasa. Kemudian, definisi dari tes ini adalah sebagai berikut. Tes ini merupakan tes menyimak untuk mahasiswa vokasi yang mengukur pemahaman mahasiswa tentang komunikasi sehari-hari di tempat kerja dan konteks kehidupan sosial. Oleh karena itu, pertanyaannya sebagian besar akan berbentuk WH-question, seperti "Apa yang disiratkan oleh orang tersebut? Dimana percakapan itu berlangsung? Apa saran wanita itu kepada laiki-laki tersebut? Kapan rapat itu akan dimulai? Siapakan orang itu?" dan sebagainya.

\section{Merencanakan Evaluasi Tes}

Evaluasi tes di sini berarti mengevaluasi kegunaan tes. Poin-poin standar yang digunakan dalam evaluasi tes adalah uji reliabilitas, validitas, keaslian, interaktivitas, dampak, dan kepraktisan. Poin-poin standar tersebut bisa menjadi panduan sehingga tes akan tetap sesuai seperti yang didefinisikan dalam konstruk tes. Harus ada prosedur untuk mengumpulkan data atau bukti yang terkait dengan kegunaan tes. Dalam tes ini evaluasi dilakukan dalam bentuk diskusi, oleh pembuat test, administrator tes, dan pengembang aplikasi web, pada akhir semester untuk mengevaluasi kegunaan tes, prestasi mahasiswa, dan permasalahan (baik teknis maupun administratif) yang muncul.

\section{Merencanakan Alokasi Waktu dan Inventaris Sumber Daya Tes}

Tes menyimak ini direncanakan akan dilakukan sekitar 30 menit yang terbagi menjadi empat bagian. Bagian pertama dan kedua akan berlangsung masing-masing selama 3-5 menit masingmasing, sementara bagian yang ketiga dan keempat masing-masing akan dilaksanakan selama 8 - 10 menit. OLIVE telah mengunggah 2 set tes menyimak yang telah diakses oleh mahasiswa secara online. Namun, ada 3 set lagi dalam persediaan yang siap diunggah. Ada tim yang bertindak sebagai administrator sekaligus yang bertanggung jawab dalam proses pengelolaan, pemantauan, dan pengembangan tes. Tim terdiri dari lima dosen dari Program Studi Bahasa Inggris Sekolah Vokasi UGM. Namun, tidak hanya kelima dosen yang memiliki hak untuk Jurnal Lingua Aplicata Volume 1, Nomor 1 September 2017 
menerapkan OLIVE di kelas mereka, namun semua dosen dari Program Studi Bahasa Inggris dapat menggunakan tes ini.

\section{Operasionalisasi}

Operasionalisasi adalah tahap kedua dari proses pembuatan tes (setelah proses desain) yang terdiri dari spesifikasi tugas tes dan pengembangan kerangka tes (blueprint), penulisan instruksi, dan spesifikasi metode penilaian (Bachman dan Palmer, 1996).

\section{Mengembangkan Tugas Tes dan Blueprint}

Untuk mengembangkan tugas tes, seorang pembuat tes harus mempertimbangkan jenis tugas yang sudah dihasilkan dalam proses perancangan. Kemudian, pembuat tes menyesuaikannya dengan merefleksikan tujuan pengujian agar menghasilkan spesifikasi tugas tes. Sementara itu, blueprint yang mencakup organisasi umum pengujian dan spesifikasi tugas tes disertakan. Hal ini akan memberikan deskripsi kepada pembuat tes tentang bagaimana tugas pengujian akan dilakukan dan bagaimana susunannya. Blueprint OLIVE diadopsi dari blueprint TEVocS (Sekolah Vokasi UGM, 2014) yang disajikan pada Gambar 2 dan 3.

\section{Menulis Instruksi}

Proses dalam menulis instruksi berarti menggambarkan struktur umum tes, bagaimana tes akan dilakukan, dan bagaimana seharusnya para peserta tes melakukan tes. Dalam OLIVE, instruksi diberikan di setiap bagian tes, sehingga akan ada empat instruksi berbeda seperti yang disajikan pada Tabel 1 (diadopsi dari TEVocS User Guide (2015)).

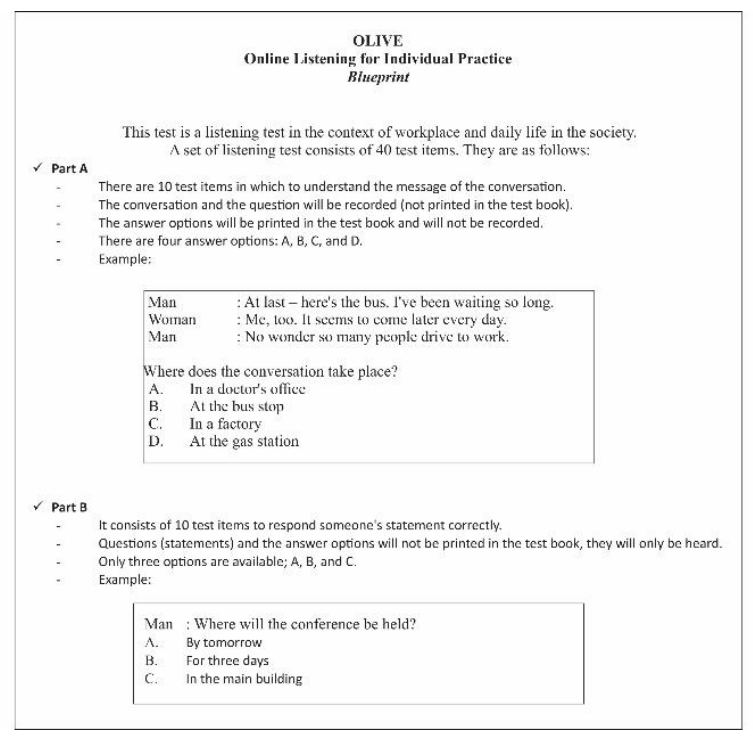

Gambar 2. Blueprint dari OLIVE (Bagian 1) 


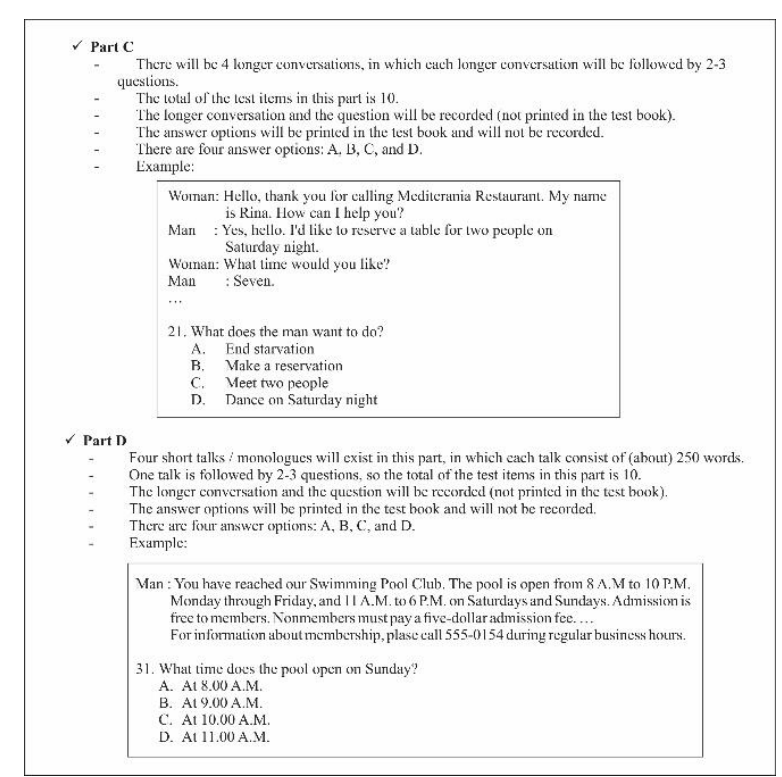

Gambar 3. Blueprint dari OLIVE (Bagian 2)

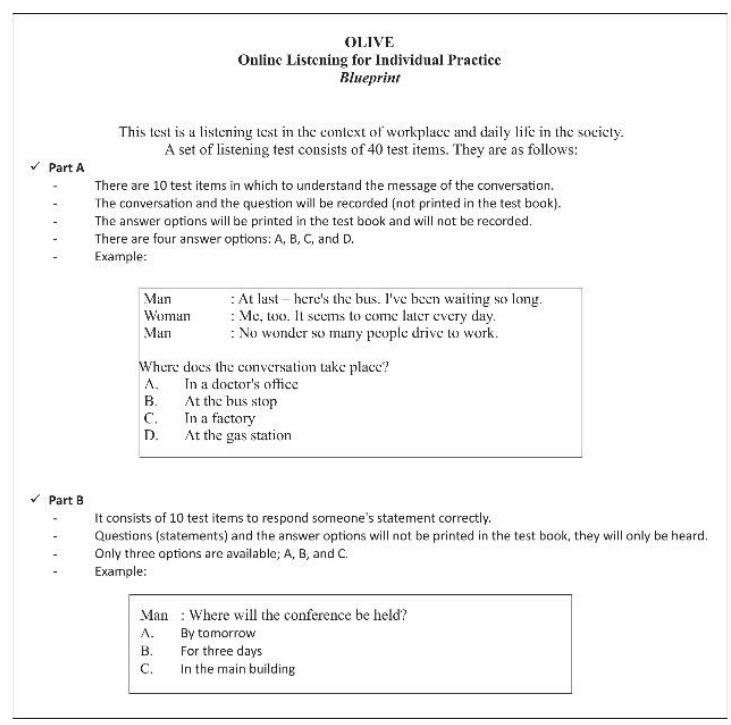

Tabel 1. Petunjuk OLIVE

langkah dalam menghitung jawaban untuk mendapatkan skor akhir.

Seperti yang disebutkan di atas, bahwa OLIVE terdiri dari 40 pertanyaan tertutup dalam bentuk pilihan ganda, akan memudahkan administrator tes untuk mengevaluasi jawaban para peserta tes. Semua jawaban yang benar akan mendapatkan poin yang sama, dan tidak akan ada pengurangan untuk jawaban yang salah. Skor maksimalnya adalah 100, sehingga masing-masing jawaban benar bernilai 2,5 poin. Dengan demikian, menghasilkan formula yang sangat sederhana untuk mendapatkan skor akhir seperti yang dinyatakan di bawah ini.

Skor akhir = jumlah jawaban yang benar x 2.5

Sebagai contoh, seorang mahasiswa memberikan 34 jawaban yang benar, penghitungannya adalah $34 \times 2,5$ dan skor akhirnya adalah 85 . peserta tes. Yang kedua adalah langkahlangkah dalam menentukan metode penilaian. Yang pertama adalah menyatakan prinsip-prinsip terkait dengan cara untuk menilai jawaban para

\section{Menentukan Metode Penilaian}

Pembuat tes melakukan dua

\section{Administrasi \\ Administrasi}

Proses administrasi bisa dilakukan dalam dua tahap, yaitu tes uji coba (tryout) dan tes operasional. Try-out dilakukan untuk mengumpulkan data tentang daya guna tes untuk meningkatkan tes tersebut. Biasanya tryout diadakan sebelum tes benar-benar Jurnal Lingua Aplicata Volume 1, Nomor 1 September 2017 
digunakan, dan umpan balik dari try-out tersebut akan digunakan untuk merevisi tes. Sementara itu, tes operasional di sini melibatkan persiapan lingkungan / tempat tes, mengumpulkan bahan tes, melatih petugas tes, melaksanakan tes, dan mengarsipkan tes (Bachman dan Palmer, 1996).

Uji coba yang telah dilakukan dalam tes ini lebih banyak untuk mengumpulkan umpan balik mengenai hal teknis, seperti apakah mahasiswa dapat masuk dan menggunakan akun mereka atau tidak, apakah skor atau hasil tesnya dapat muncul atau tidak, dan apakah rekaman suaranya bisa dimainkan dan didengarkan oleh mahasiswa dengan baik atau tidak. Langkah ini menjadi krusial karena proses pengembangan aplikasi online dibantu oleh pengembang web, sehingga pembuat tes memerlukan umpan balik dari para mahasiswa sebagai peserta tes dalam hal mengakses aplikasi yangmana umpan balik tersebut akan diajukan ke pengembang web.

Selain itu, dalam tes operasional OLIVE, pembuat tes menyiapkan lingkungan tes dengan menyiapkan prosedur untuk melakukan pengujian bagi peserta tes, mengumpulkan bahan tes dengan membuat rangkaian tes baru, melatih para administrator / operator tes dengan mengadakan pelatihan tentang penggunaan tes dan aplikasinya dengan berkolaborasi dengan pengembang web, melaksanakan tes dengan benar-benar menggunakan tes secara online, dan mengarsipkan tes dengan mengunggah rangkaian tes dalam inventaris tes dalam aplikasi OLIVE.

\section{Kesimpulan dan Saran}

Proses pembuatan item tes OLIVE mencakup tiga tahap; desain, operasionalisasi, dan administrasi. Proses perancangan terdiri dari enam tahap, yaitu menggambarkan tujuan tes, menggambarkan bidang dan jenis tugas, menggambarkan peserta tes, mendefinisikan konstruk tes, merencanakan evaluasi tes, dan merencanakan alokasi waktu dan inventaris sumber daya tes. Lalu, ada tiga langkah yang terdapat dalam operasionalisasi. Langkah-langkah tersebut adalah mengembangkan tugas tes dan blueprint, menulis instruksi, dan menentukan metode penilaian. Tahap yang terakhir adalah administrasi. Proses administrasi dilakukan dengan melakukan try-out dan tes operasional.

Ketiga tahap tersebut diatas menghasilkan empat puluh item tes, yang 
terbagi menjadi empat bagian yangmana masing-masing hanya akan diputar satu kali saja. Bagian pertama adalah Percakapan Singkat. Di bagian tes ini, peserta tes akan menyimak sepuluh percakapan singkat. Pada akhir setiap percakapan singkat, mereka akan membaca sebuah pertanyaan dan empat pilihan jawaban pada buku ujian dan peserta ujian harus memilih jawaban yang paling tepat sesuai dengan pertanyaannya. Bagian kedua adalah Tanya-Jawab. Dalam bagian tes ini, peserta tes akan mendengar sepuluh pertanyaan / pernyataan. Setelah mendengar setiap pertanyaan / pernyataan mereka akan mendengar tiga kemungkinan tanggapan. Mereka harus memilih jawaban / tanggapan yang terbaik menjawab pertanyaan / pernyataan tersebut. Berikutnya adalah Percakapan Panjang. Di bagian tes ini, peserta tes akan mendengar beberapa percakapan panjang antara dua orang. Setelah mendengar setiap percakapan, mereka akan mendengar dua sampai tiga pertanyaan. Mereka dapat membaca empat pilihan jawaban untuk setiap pertanyaan di buku ujian. Mereka harus memilih jawaban yang paling tepat menjawab pertanyaan. Pertanyaannya akan menanyakan tentang gagasan umum serta hal-hal rinci terkait percakapan tersebut. Yang terakhir adalah monolog. Dalam bagian tes ini, peserta tes akan mendengar beberapa monolog. Setelah mendengar setiap monolog mereka akan mendengar dua atau tiga pertanyaan tentang monolog tersebut. Mereka dapat membaca empat pilihan jawaban dalam buku ujian. Mereka harus memilih jawaban yang paling tepat dari setiap pertanyaanPertanyaan pada bagian ini akan menanyakan tentang ide umum serta rincian spesifik dalam pembicaraan (Sekolah Vokasi UGM, 2015).

Manfaat langsung dari OLIVE dapat diperoleh oleh mahasiswa program studi non-bahasa Inggris. Tes online sebagai bahan pelengkap mata kuliah mereka ini tersedia bagi mereka yang bisa diakses kapan dan dimana saja. Selain itu, proses pembelajaran tidak selalu dilakukan di kelas. Lebih dari itu, mereka dapat melihat kemajuan hasil belajar mereka saat menggunakan e-learning. Selanjutnya, OLIVE memberikan keuntungan tidak langsung karena meningkatkan pemanfaatan e-learning di kelas dan mendukung aplikasi e-learning di UGM. Penggunaan e-learning tidak 
hanya dapat diaplikasikan untuk keterampilan menyimak saja, tapi juga untuk keterampilan bahasa lainnya dimana para pembuat tes harus tetap mempertimbangkan tahapan dalam membuat item tes agar dapat menghasilkan item tes yang berkualitas.

\section{Referensi}

Bachman, L.F. \& Palmer, A.S. (1996). Designing and developing useful language tests. Oxford: Oxford University Press.

Brown, H.D. (2001). Teaching by principles: An interactive approach to language pedagogy. $2^{\text {nd }}$ ed. New York: Addison Wesley Longman, Inc.

Brown, H.D. (2004). Language assessment: Principles and classroom practices. New York: PearsonEducation, Inc.

Christian, A.C.C. (2005). Promoting independent learning through language learning and the use of IT. Educational Media International. Dec2005, Vol. 42 Issue 4, p317-332. Retrieved from http://web.a.ebscohost.com/ehost/p dfviewer/pdfviewer?vid=28\&sid=893 fc203-9aec-4b79-9091e398b7820263\%40sessionmgr4008

Fulcher, G. (2010). Practical language testing. London: Hodder Education.

Fulcher, G. \& Davidson, F. (2007). Language testing and assessment: An advance resource book. New York: Routledge.

Henning, G. (1987). A guide to language testing: Development, evaluation and research. Boston: Heinle\& Heinle Publishers.
Hughes, A. (2002). Testing for language teachers, $2^{\text {nd }}$ ed. Cambridge: Cambridge University Press.

Hussain, H. (2005). The usage of e-learning material to support good communication with learners. Issues in Informing Science \& Information Technology. 2004, Vol. 1, p1005-1015. Retrieved from http://web.a.ebscohost.com/ehost/p dfviewer/pdfviewer?vid=17\&sid=893f c203-9aec-4b79-9091e398b7820263\%40sessionmgr4008

Kantelinen, R. \& Airola, A. (2009). Towards a better quality and comparability of language education in Finnish Polytechnics. Scandinavian Journal of Educational Research, 53(1), 35-51.

Kavaliauskienè, G. \& Anusienè, L. (2009). English for specific purposes: Podcasts for listening skills. Coactivity LSantalka. 2009, Vol. 17 Issue 2, p28-37. Retrieved from http://web.a.ebscohost.com/ehost/p dfviewer/pdfviewer?vid=20\&sid=893 fc203-9aec-4b79-9091e398b7820263\%40sessionmgr4008

Kopriva, R.J. (2008). Improving testing for English language learners. New York: Routledge.

Kumar, A.M. (2008). Computer-assisted language learning to improve the quality of higher education: Advantages and disadvantages. Computer Science (1407-7493). 2008, Vol. 34, p28-36. Retrieved from http://web.a.ebscohost.com/ehost/p dfviewer/pdfviewer?vid=32\&sid=893 fc203-9aec-4b79-9091e398b7820263\%40sessionmgr4008

Sekolah Vokasi Universitas Gadjah Mada. (2014). TEVocS blueprint.

Sekolah Vokasi Universitas Gadjah Mada. (2015). TEVocS user guide. 
Sekolah Vokasi Universitas Gadjah Mada.

(2017). Keputusan dekan Sekolah

Vokasi Universitas Gadjah Mada

nomor 10/UN1.SV/SK/2017 tentang

persyaratan kelulusan bagi

mahamahasiswa Sekolah Vokasi

Universitas Gadjah Mada.

Tuckman, B. W. (1975). Measuring educational outcome: Fundamentals of testing. California: Harcourt Brace Jovanovich, Inc.

Young, S.S.C. (2003). Integrating ICT into second language education in a vocational high school. Journal of Computer Assisted Learning, 19, 447461. 